\title{
ANALISIS DATA RESISTIVITY UNTUK MENENTUKAN POTENSI BENCANA TANAH LONGSOR DI KAMPUNG LEGOK HAYAM, DESA GIRIMEKAR, KECAMATAN CILENGKRANG, KABUPATEN BANDUNG
}

\section{RESISTIVITY DATA ANALYSIS FOR DETERMINING THE POTENTIAL LANDSLIDE IN LEGOK HAYAM AREA VILLAGE OF GIRIMEKAR, CILENGKRANG DISTRICT OF BANDUNG REGENCY}

\author{
Bambang Marwanta \\ Pusat Teknologi Reduksi Risiko Bencana BPPT - Puspiptek Serpong, \\ e-mail: bmarwanta@yahoo.com
}

\begin{abstract}
Girimekar village Cilengkrang District of Bandung Regency is a region prone to landslides. This region has 800 meters height above sea level. The morphology in this area is hilly with gradient of slopes $10^{\circ}$ to $40^{\circ}$. Landslides in the area often occur during the rainy season. To determine the condition of the subsurface configuration that cause of ground movement in the region, using measurements with resistivitymeter. Resistivity data were processed using RES2DINV (2D Resistivity Inversion) and modeled in subsurface profile that describes a $2 D$ surface layer of soil or rock with different resistivity values. Resistivity measurements carried out 7 th line in locations where there has been ground movement. From the results of the modeling data interpretation it is known patterns of soil layering in the area, with direction of movement of soil to the west. Boundary weathered layer with sliding plane which is approximately 20 meters depth. This layer interpreted with tuffas sandstone and volcanic sediment, with a resistivity of 10-20 ohm meter. While the sliding plane field of clay with resistivity 100-200 ohm meter. To ensure the type of rock which was described in the resistivity profiles of data requires drilling or interpretation of geological data around the site.
\end{abstract}

Keywords: Landslide Potential, Girimekar, Resistivity, 2D

\begin{abstract}
ABSTRAK
Desa Girimekar Kecamatan Cilengkrang Kabupaten Bandung merupakan wilayah yang rawan longsor. Wilayah ini mempunyai ketinggian $800 \mathrm{mdpl}$ ini merupakan morfologi perbukitan dengan kelerengan $10^{\circ}$ hingga $40^{\circ}$. Longsor di daerah tersebut sering terjadi pada waktu musim hujan. Untuk mengetahui diketahui profil bawah permukaan yang menjadi penyebab terjadinya gerakan tanah di wilayah tersebut, dilakukan investigasi dengan menggunakan pengukuran dengan resistivitymeter. Data resistivitas diolah dengan menggunakan RES2DINV (2D Resistivity Inversion) dan dimodelkan dalam profil bawah permukaan yang menggambarkan 2D lapisan permukaan tanah atau batuan dengan nilai resistivitas yang berbeda. Pengukuran resistivity dilakukan pada 7 line pada lokasi yang mana sudah terjadi gerakan tanah. Dari hasil interpretasi data pemodelan maka diketahui pola perlapisan batuan di daerah telitian, dengan arah gerakan tanah menuju ke arah barat. Batas lapisan lapuk dengan bidang gelincir relatif dalam, yaitu sekitar 20 meter. Lapisan lapuk diinterpretasikan dengan batuan pasir tufaan dan endapan gunung api terlapukkan, dengan resistivitas 10-20 ohm meter. Sedangkan bidang gelincirnya merupakan lempungan dengan resistivitas 100-200 ohm meter. Untuk memastikan jenis batuan yang tergambar dalam profil resistivity tersebut perlu dilakukan data pemboran atau interpretasi dari data geologi yang tersingkap di sekitar lokasi telitian.
\end{abstract}

Kata kunci: Potensi Longsor, Girimekar, Resistivity, 2D 


\section{PENDAHULUAN}

\subsection{Latar Belakang}

Jawa Barat termasuk salah satu provinsi yang mempunyai tingkat risiko bencana tanah longsor paling tinggi dibandingkan dengan provinsi lain di Indonesia. Longsor terjadi pada daerah-daerah pegunungan, berlereng terjal, dan sering terjadi oleh 2 faktor, akibat alam (curah hujan yang tinggi) dan ulah manusia yang sifatnya merusak lingkungan di sekitarnya (Naryanto, 2004).

Pada awal tahun 2010 terjadi gerakan tahan di Kampung Legok Hayam, Desa Girimekar, Kecamatan Cilengkrang, Kabupaten Bandung, yang mengakibatkan puluhan rumah bergeser dan mengalami kerusakan struktur. Gerakan tanah disertai longsoran kecil terjadi terus menerus dalam kurun beberapa waktu. Laporan tahunan dari Badan Penanggulangan Bencana Daerah (BPBD) Provinsi Jawa Barat tahun 2013 juga menyebutkan bahwa pada tanggal 9 Februari 2013 juga terjadi kejadian bencana tanah longsor di Desa Girimekar, Kecamatan Cilengkrang. Dilaporkan longsor mengakibatkan 2 rumah hancur, dengan dimensi longsor sepanjang 30 meter dan ketinggian tebing 7 meter. Longsor dipicu karena curah hujan yang tinggi. Pada tahun 2016 inipun juga terjadi kejadian penggerusan tanah di Kompleks Girimekar Permai RT 1 RW 21 Desa Girimekar yang mengakibatkan beberapa rumah rusak. Faktor kejenuhan air dan sungai di bawahnya berperan dalam kejadian ini. Kejadian seperti ini juga terjadi pada tahun-tahun sebelumnya.

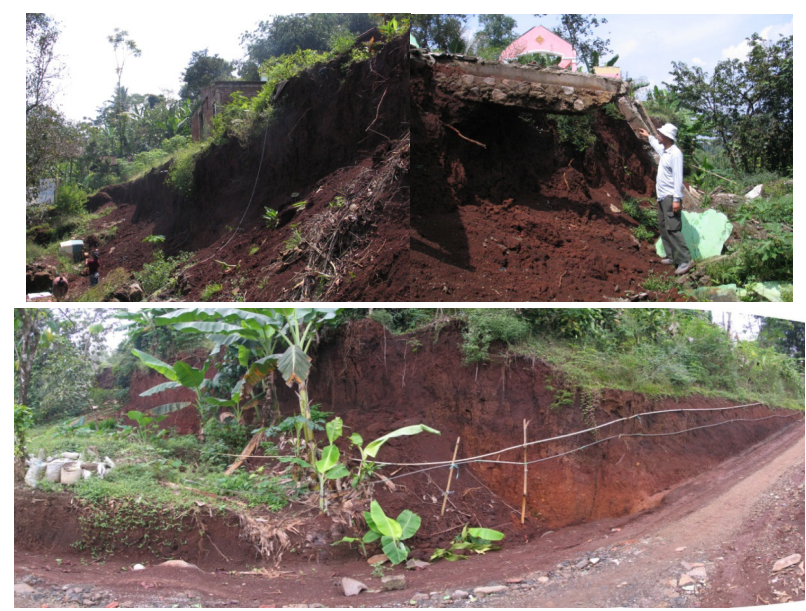

Gambar 1. Situasi Daerah Longsor Kampung Legok Hayam

Dengan kondisi seperti uraian di atas, maka perlu diketahui profil bawah permukaan yang menjadi penyebab sering terjadinya kejadian gerakan tanah di wilayah tersebut. Tulisan ini akan mengulas tentang profil bawah permukaan di daerah Kampung Legok Hayam, Desa Girimekar, Kecamatan Cilengkrang, Kabupaten Bandung yang mengalami bencana gerakan tanah. Metode untuk mengetahui profil kondisi bawah permukaan ini dengan menggunakan peralatan geolistrik yang dilakukan pengukuran di beberapa tempat di daerah penelitian.

\subsection{Tujuan}

Tujuan dari penelitian ini adalah untuk mengetahui profil bawah permukaaan dengan mengunakan pengukuran data resistivity. Dari gambaran tersebut maka dapat ditentukan massa yang potensi bergerak arah mana acaman bencana gerakan tanah ini akan terus berlangsung, sehingga pengurangan risiko bencana dapat dilakukan sejak dini.

\section{METODE PENELITIAN}

Lokasi penelitian pemetaan bawah permukaan menggunakan data resistivity ini berada di Kampung Legok Hayam, Desa Girimekar, Kecamatan Cilengkrang, Kabupaten Bandung. Desa ini terletak $\pm 3 \mathrm{~km}$ di sebelah utara jalan raya Ujung Berung atau sekitar $7 \mathrm{~km}$ dari terminal Cicaheum Bandung. Daerah ini berada di kaki bukit dengan kelerengan $10^{\circ}$ hingga $40^{\circ}$ dengan ketinggian sekitar 800 mdpl. Longsor yang terjadi di desa ini membentang sepanjang \pm 300 meter pada area seluas 1 ha yang merobohkan belasan rumah pemukiman penduduk.

Pengukuran resistivity dilakukan pada tanggal 23-24 September 2010, dengan menggunakan alat pengukuran resistivitymeter type ARES G-4 single receiver. Dari pengukuran resistivity $2 \mathrm{D}$ dengan berbagai lintasan yang sudah direncanakan, data yang diperoleh diolah dengan menggukanan Res2Dinv (Resistivity 2D Inversion). Pengolahan dan pemodelan data Tahanan Jenis 2D digunakan program inversi.

Dari hasil pemodelan 2D, maka dilakukan interpretasi profil bawah permukaan untuk menentukan litologi dan profil perlapisan dalam menganalisis potensi gerakan tanah di lokasi telitian. Untuk memperoleh model tahanan jenis 2D yang mendekati keadaan geologi bawah permukaan yang sebenarnya, maka sebagai acuan diperlukan beberapa data harga tahanan jenis beberapa jenis batuan secara teoritis, maupun data geologi, baik berupa peta geologi maupun 
data tentang singkapan batuan yang dapat diamati di permukaan sebagai referensi batuan setempat.

\section{HASIL DAN PEMBAHASAN}

\subsection{Pengambilan data resistivity}

Peralatan yang digunakan untuk memetakan bawah permukaan adalah resistivitymeter type ARES G-4 single receiver dengan kemampuan transmitter 2 Ampere yang dilengkapi dengan switch-box 48 channels dengan 48 elektroda yang masing-masing elektroda berjarak 5 meter dengan total panjang bentangan hingga 235 meter. Konfigurasi yang digunakan dalam pengukuran ini dengan menggunakan metode Wenner.

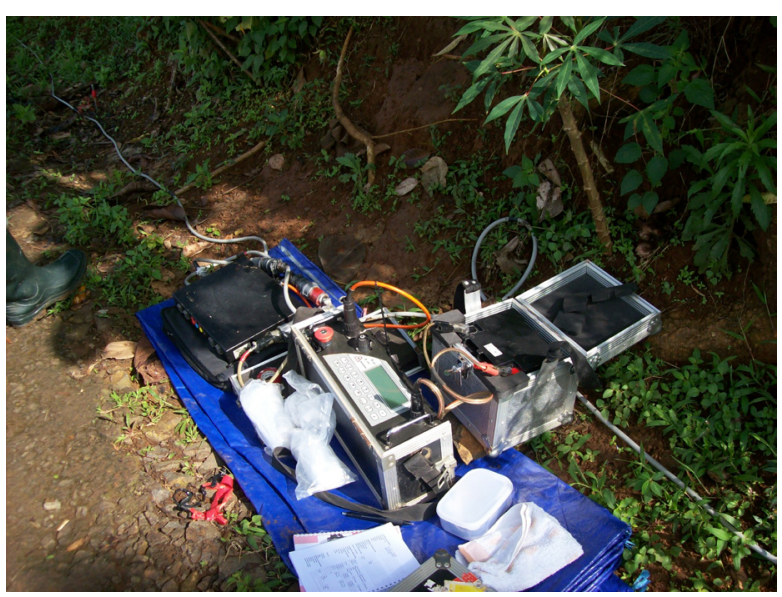

Gambar 2. Peralatan Geolistrik

Harga resistivity (tahanan jenis) yang dihitung bukan merupakan harga tahanan jenis yang sebenarnya dari bawah permukaan, tetapi merupakan harga semu di mana tahanan jenis dari tanah/batuan yang homogen akan memberikan harga resistansi yang sama untuk susunan elektroda yang sama. Hubungan antara tahanan jenis semu dengan tahanan jenis yang sebenarnya merupakan hubungan yang kompleks. Untuk menentukan dan memodelkan harga tahanan jenis bawah permukaan sebenarnya, di antaranya dapat dilakukan dengan menggunakan program inversi dari harga tahanan jenis semu terukur menggunakan program komputer.

Sebelum data hasil pengukuran dimasukkan ke dalam program tersebut terlebih dahulu dihitung besarnya harga tahanan jenis semu $\left(\rho_{\mathrm{a}}\right)$ dengan memasukkan faktor geometri konfigurasinya. Datadata tesebut disusun sesuai dengan format input file untuk program pengolahan dan pemodelan, dan dimasukkan ke dalam program untuk dilakukan pemodelan inversi dengan memberikan beberapa parameter model sehingga diperoleh hasil yang diharapkan.

Lintasan pengukuran geolistrik yang direncanakan untuk mendapatkan gambaran yang mencukupi untuk menggambarkan keadaan bawah permukaan di sekitar lokasi longsor sebanyak 7 buah lintasan masing-masing sepanjang 235 meter dengan jarak antar lintasan 70-100 meter seperti digambarkan dalam Gambar 3 berikut ini.

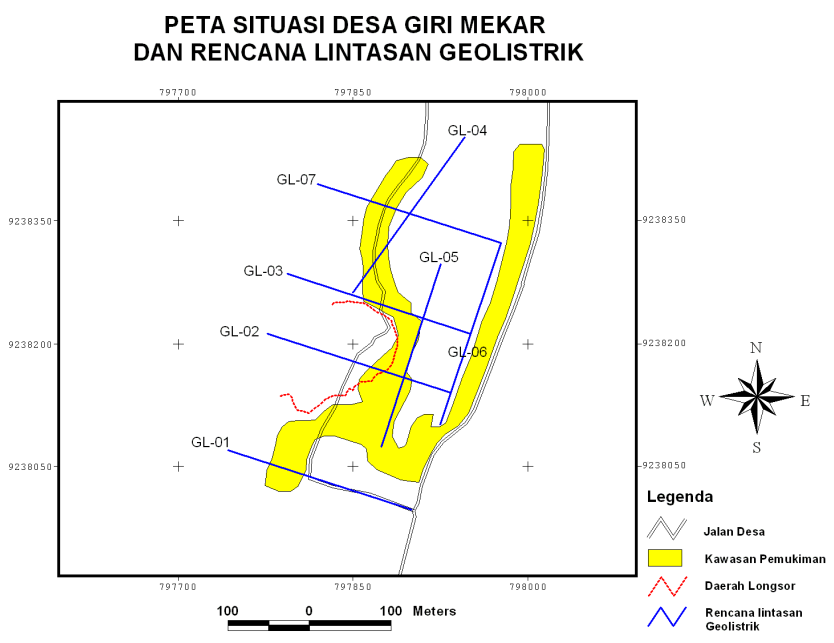

Gambar 3. Peta Lintasan Pengukuran Geolistrik

\subsection{Hasil Pengukuran dan Analisa}

Hasil inversi dari masing-masing profil lintasan menggambarkan nilai tertinggi dan terendah yang terekam pada lintasan tersebut, sehingga profil setiap lintasan geolistrik akan memperlihatkan rentang nilai resistivity yang berbeda. Untuk memudahkan dalam menginterpretasi hasil inversi dari seluruh lintasan diperlukan penyeragaman rentang nilai resistivity yang digunakan.

Melihat hasil inversi pada lintasan GL-02 yang tepat melintas di tengah area longsor dan hasil penampang bawah permukaannya yang relatif bersesuaian dengan kondisi lapangan maka untuk sementara digunakan rentang nilai resistivity pada lintasan GL-02 sebagai nilai acuan untuk keseluruhan lintasan geolistrik sehingga hasil penampang bawah permukaan dikoreksi sebagai berikut: 


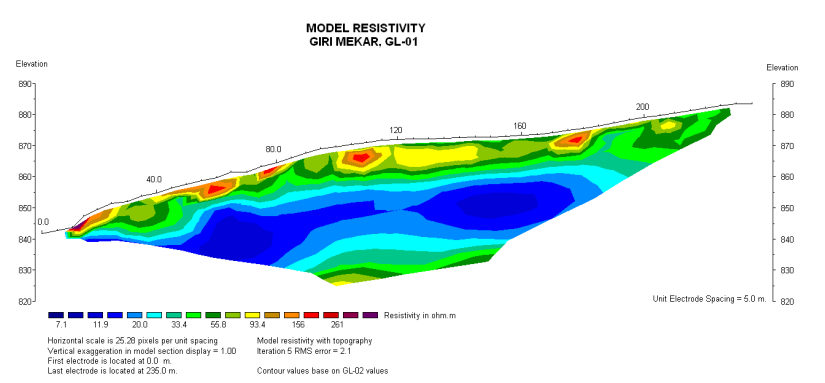

Gambar 4. Profil Lintasan GL -01, Arah Timur Barat

Pengukuran pertama ini dilakukan di sisi paling selatan dari area investigasi. Diukur mengikuti jalan desa yang merupakan di atas antara permukiman dengan tegalan. Hasil yang didapatkan berupa profil resistivitas bawah permukaan seperti yang terlihat pada Gambar 4 di atas. Dari hasil inversi, diinterpretasikan bahwa di bagian permukaan adalah lapisan lebih keras. Ini bisa dipahami karena yang diukur mengikuti jalan beraspal, sehingga imbas batuannya menyebabkan tahanan jenisnya lebih besar. Yang menarik kelompok lapisan kedua dengan kedalaman 5 sampai 20 meter mempunyai nilai tahanan jenis yang tinggi dengan kisaran 10$20 \mathrm{ohm}$ meter. Ini bisa ditafsirkan bahwa di lapisan tersebut merupakan lapisan lapuk jenuh air. Batas lapisan ketiga adalah lapisan dengan kedalaman 20 meter ke bawah, merupakan batas dengan lapisan lapuknya, dengan resistivitasnya mendekati angka $100 \mathrm{ohm}$ meter, yang merupakan bidang penyangganya. Potensi longsor ada, tetapi sangat kecil, karena selain kedalaman lapisan lapuknya, juga terlihat ada profil menonjol di tengah lintasan.

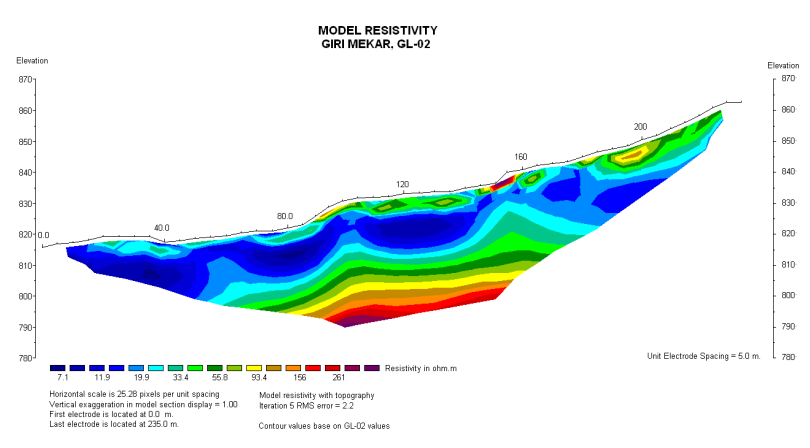

Gambar 5. Hasil Inversi Lintasan GL -02, Bidang Gelincir Mulai Terlihat Berupa Cekungan

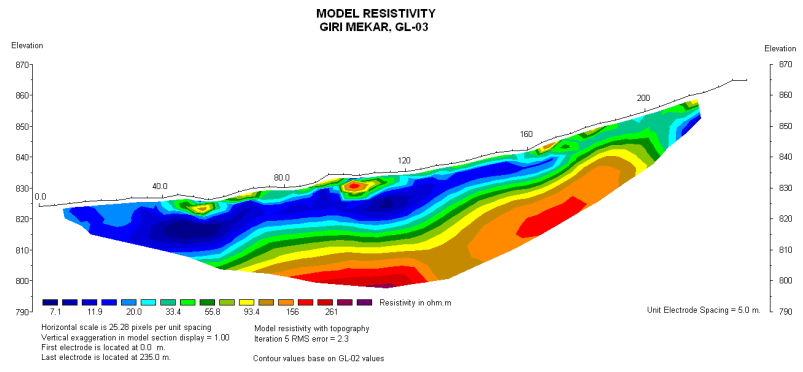

Gambar 6. Profil Bawah Permukaan Lintasan 03, yang Masih Paralel dengan Lintasan 02

Hasil interpretasi dari pengukuran lintasan 02 dan 0 menghasilkan profil yang relatif mirip, karena letak lintasan yang berdekatan dan arah lintasan yang sama, yaitu tenggara - baratlaut. Dari dua profil yang ada terlihat bahwa batas lapisan lapuk dengan bidang gelincir relatif dalam, yaitu sekitar 20 meter. Lapisan lapuk diinterpretasikan dengan batuan pasir tufaan dan endapan gunung api terlapukkan, dengan resistivitas 10-20 ohm meter. Sedangkan bidang gelincirnya merupakan lempungan dengan resistivitas 100-200 ohm meter. Dari dua profil di atas dapat diketahui bahwa bidang gelincir tidak lurus dengan sudut derajat kemiringan tertentu, tetapi membentuk cekungan dengan lebar 40 meteran dan berulang ulang. Ini bisa dikaitkan dengan fenomena tanah amblas seperti yang di beritakan di media-media sebelumnya.

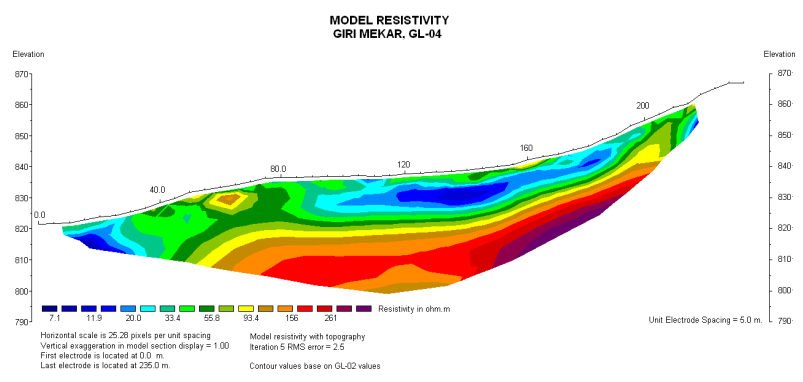

Gambar 7. Hasil Inverse Lintasan Pengukuran Ke 4, Bidang Gelincir Sangat Terlihat.

Pengukuran ke 4 ini berarah baratdaya timurlaut. Dari hasil inversi profil bawah permukaan terlihat jelas ada kemiringan lapisan batuan. Lapisan atas dengan resistivitas yang lebih rendah terlihat terjebak oleh lapisan yang kedap air di bawahnya. Kedalamannya mencapai 10 sampai 15 meter dengan harga resistivitas 10-20 ohm meter, yang diinterpretasikan sebagai lapukan produk gunung api, pasir tufaan. Sedangkan lapisan di bawahnya dikelompokkan lapisan impermeable dengan harga resistivitas 200-300 ohm meter yang diindikasikan sebagai batuan lempung. Pada posisi ke bawah terganjal oleh batuan yang berhubungan 
dengan lapisan lempungnya, sehingga gerakannya agak tertahan di sana dan cenderung amblas.

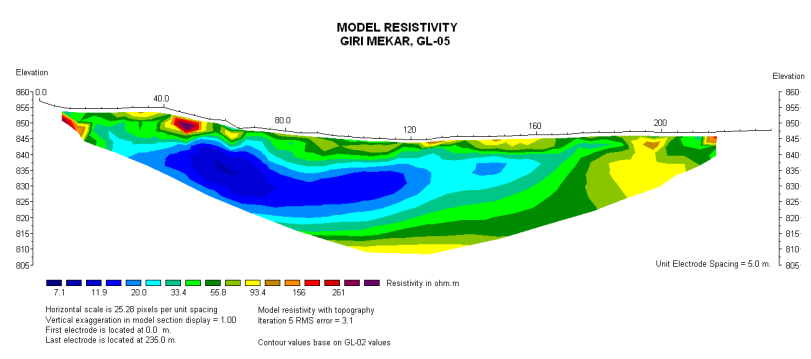

Gambar 8. Hasil Inversi Lintasan Ke 5, Arah Relatif Utara - Selatan.

Pengukuran ke 5 ini melengkapi profil arah utara - selatan relatif. Hasil pengukuran memperlihatkan pola yang sama, yaitu di atas relatif besar resistivitasnya dengan kedalaman hingga 5 meter yang diinterpretasikan sebagai bahan rombakan dan material bangunan. Sedangkan di bawahnya adalah lapisan lapuk asli dengan kedalaman hingga 20 sampai 30 meter dengan kejenuhan air yang tinggi. Pola perlapisan, berhenti di sisi utara atau sisi atas.

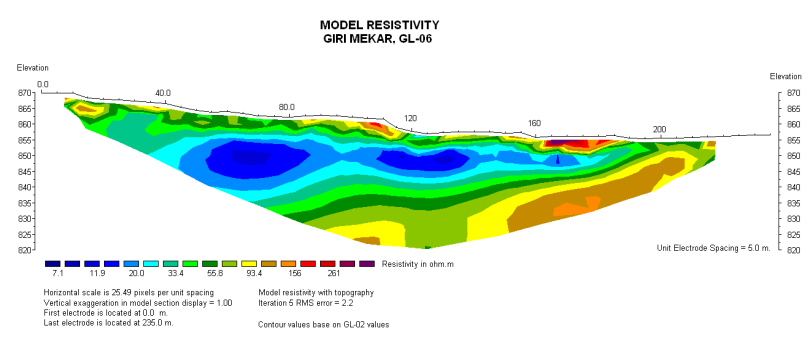

Gambar 9. Hasil Inverse Pengukuran Lintasan Ke 6, Arah Relatif Utara - Selatan, Sisi Timur Lintasan Sebelumnya

Dua lintasan di atas (lintasan 5 dan 6) menghasilkan profil bawah permukaan yang tegak lurus dari arah bidang kemiringan longsor. Dari profil yang ada terlihat bahwa di kelompok lapisan atas (sampai 5 meter) mempunyai resistivitas yang tinggi hingga 50 ohm meter. Ini dapat dipahami karena menyangkut infrastruktur yang ada di sana, termasuk rumah rumah penduduk, jalan. Di bawahanya merupakan lapisan lapuk dengan resistivitas yang rendah 10-20 ohm meter dengan kedalaman hingga 30 meter. Dari profil juga menggambarkan lapisan lapuk tidak menerus, di sisi selatan terlingkupi dengan lapisan dengan resistivitas yang lebih besar hingga 200 ohm meter.

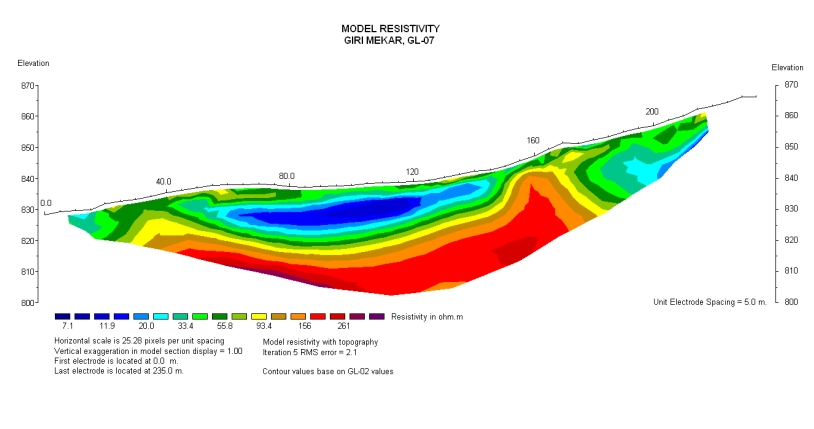

Gambar 10. Gambaran Lapisan Bawah

Permukaan Dari Lintasan Ke 7, yang Paralel dengan Lintasan 01, 02 dan 03

Pengukuran ke 7 ini mengarah seperti pada pengukuran ke 1, 2 dan 3, yaitu tenggara baratlaut. Dari hasil pengukuran ke 7 ini, dapat menggambarkan lapisan lapuknya hingga 20 meter, dengan resistivitasnya 10-20 ohm meter, yang diinterpretasikan sebagai lapisan lapuk produk gunung api, seperti pasir tufaan. Di bawahnya merupakan lapisan kedap air dengan resistivitas yang relatif tinggi, yaitu 100-250 ohm meter. Lapisan kedapnya membentuk cekungan seperti terlihat di lintasan 2 dan 3.

\subsection{Potensi Daerah Rawan Longsor}

Untuk memudahkan memvisualisasikan penampang dalam menganalisis karakteristik bawah permukaan, keseluruhan penampang disusun dalam posisi 3 dimensi menggunakan bantuan software Goggle Sketch-up

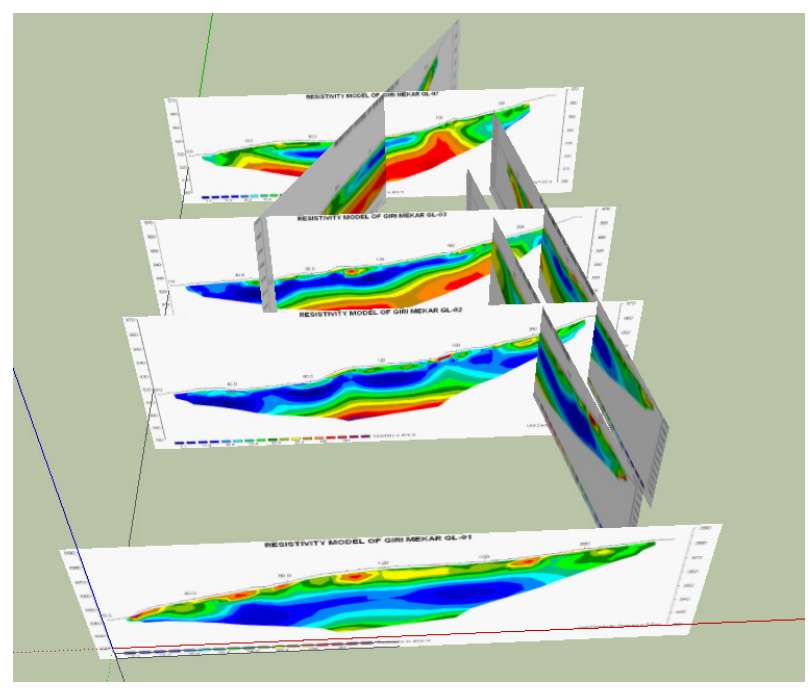

Gambar 11. Profil Gabungan Semua Lintasan yang Digambarkan Sesuai Letak Pengukuran

Dari semua hasil pengukuran, potensi longsoran tanah dengan sifat slidenya tidak terlihat pada sisi bidang gelincirnya. Batas antara lapisan lapuk 
dengan impermiablenya membentuk cekungan cekungan seperti terlihat di lintasan 2 dan 3. Tetapi jika diambil garis besarnya, potensi gerakan tanah ada di sekitar lintasan 3 , bagian tengan relatif amblas. Sedangkan di lintasan 2 cenderung slide, seperti terlihat di bidang gelincirnya. Lintasan 7 menggambarkan kecenderungan amblas pada profil tengah lintasan. Lintasan ke 4 juga yang berarah baratdaya - timurlaut juga mendukung terjadinya gerakan tanah menuju kearah barat seperti kecenderungan pada lintasan 1, 2, dan 3 .

\section{KESIMPULAN}

Desa Girimekar, Kecamatan Cilengkrang, Kabupaten Bandung merupakan daerah yang rawan terhadap gerakan tanah. Faktor penyebab gerakan tanah adalah curah hujan, kemiringan lereng, struktur geologi, keadaan batuan, tata guna lahan, dan adanya getaran. Dari sejarah kejadian longsor di Indonesia, fakta menunjukan bahwa faktor curah hujan merupakan faktor dominan yang secara umum sebagai pemicu terjadinya gerakan tanah. Menurut data PVMBG, secara geologi tanah di lokasi kejadian berupa pasir tufaan dan lapili, sedangkan di lapisan bawah berupa lempung lunak dan pasir yang mudah longsor jika tergerus air dengan intensitas tinggi (Silitonga, 1973).

Dari profil 2D yang dihasilkan pada pengolahan data resistivity, sudah diketahui pola perlapisan batuan di daerah telitian, yaitu gerakan tanah mengarah ke arah barat, yang dibuktikan dari profil lintasan 1, 2, 3, dan 7. Dari profil 2 dan 3 terlihat bahwa batas lapisan lapuk dengan bidang gelincir relatif dalam, yaitu sekitar 20 meter. Lapisan lapuk diinterpretasikan dengan batuan pasir tufaan dan endapan gunung api terlapukkan, dengan resistivitas 10-20 ohm meter. Sedangkan bidang gelincirnya merupakan lempungan dengan resistivitas 100-200 ohm meter. Untuk memastikan jenis batuan yang tergambar dalam profil resistivity tersebut perlu dilakukan data pemboran atau minimal interpretasi dari data geologi yang tersingkap di sekitar lokasi penelitian.

\section{DAFTAR PUSTAKA}

Anonim. 2007. Res2Dinv Ver 3.56, Rapid 2-D Resistivity \& IP Inversion using the leastsquares method, Geoelectrical Imaging 2D \& 3D Geotomo Software Malaysia.

Naryanto, H.S. 2004. Potensi dan Mitigasi Bencana Tanah Longsor di Jawa Barat, Buku Permasalahan Kebijakan dan Penanggulangan Bencana Longsor di Indonesia. BPPT, Jakarta

Silitonga, P.H. 1973. Peta Geologi Lembar Bandung, Direktorat Geologi. Bandung.

Thelford, W.M., L.P. Geldard, R.E. Sheriff, D.A. Keys. 1982. Applied Geophysics. Cambridge University Press. London. 